\title{
DETERMINATION OF STEADY STATE OF NIGERIA'S ECONOMIC GROWTH; VECTOR AUTOREGRESSIVE ANALYSIS
}

\author{
Agya, Atabani Adi \\ Doctoral Research Scholar \\ Capital University of Economics and Business, Beijing, China
}

Doi: 10.19044/elp.v1no2a1 URL:http://dx.doi.org/10.19044/elp.v1no2a1

\begin{abstract}
The paper focuses on the prediction of steady state of Nigeria's economy; the data covers the period of 1970-2012, unit root test result shows that the variables were not stationary at level and they became stationary at first differencing and are integrated of I(1). Using the Vector Autoregressive co-integration test procedure, a long run relationship was found to exist among Gross Domestic products (GDP), Interest rate, Population Growth and Depreciation rate. The model has a self-adjusting mechanism for correcting any deviation of the variables from its long run equilibrium. The result shows that GDP will reach it steady state in 31to 32years, interest rate will reach it steady state in 11 to 12 years, population growth will reach steady state in16 to 17 years and depreciation rate will become stationary at 20 to 21 years in Nigeria economy. The following recommendations were; (1) that policy makers should increase the level production at the moment and moderate it in future as the economy has not reach the golden state of production yet (2) interest rate should be reduced to boost investment (3) policy aimed at moderating population growth rate should be encouraged (4) lastly, infrastructural facilities should be put in place to augment the existing ones which will go a long way in reducing the depreciation of fixed capital in the economy.
\end{abstract}

Keywords: Determination of Steady state, Nigeria's Economic Growth, Vector Autoregressive Analysis

\section{Introduction}

Developed and developing countries alike has come to believed that an ever expanding economy is a panacea to solving societal problem of poverty, distribution, population growth, food production and unemployment 
in their economy. This problems could be better solved if the economy is operating in a steady state of growth. Nigeria like any other country of the world has experience tremendous economic growth since independence; successive governments seek such an increase and do everything in their power to make it come about. To them growth is good, and the bigger the better. Governments have two objectives - to foster economic growth, and to manage its consequences. Ever increasing economic growth is over emphasized above a steady state of economic growth that is potentially more beneficial to the society. In microeconomic theory the optimal scale of a microeconomic activity production of a company or consumption of a household is determined at the point where marginal costs equal marginal revenue.

The law of decreasing marginal benefit indicates that after the point of optimal scale further growth becomes uneconomic, because costs are higher than benefit. Neoclassical economics does not demand economic growth as such, but it provides the theoretical preconditions for it and sees it as "axiomatic necessity" (Georgescu-Roegen 1977). Orthodox economists are convinced that only economic growth can solve the 'classical problems' of society, formulated by Smith (poverty), Malthus (overpopulation), Marx (distribution) and Keynes (involuntary unemployment). Not only that, it is also offered as a (or the only) remedy for pollution problems, debt repayments, balance of payment deficits, depletion of natural resources, crime, etc.

The article is structured as follows: The next section present literatures review, section three highlights the methodology employed in the study and the sources of data. Empirical results and analysis will be done in fourth section while the discussion is completed by conclusions and policy recommendation in section five.

\section{Literature Review}

Stationary state was first mentioned by Adam Smith "The Wealth of Nations" (Smith, 1776) although he certainly laid the foundations of the future growth paradigm, he did not believe that growth would be possible indefinitely. Daly (1991) opined that, an economy with constant stocks of people and artifacts, maintained at some desired, sufficient levels by low rates of maintenance 'throughput', that is, by the lowest feasible flows of matter and energy from the first stage of production to the last stage of consumption. Smith (1776) predicted that in the long run, population growth would push wages down, natural resources would become increasingly scarce, and division of labor would approach the limits of its effectiveness. He even predicted 200 years as the longest period of growth, followed by population stability. Mill (1909) developed the idea of the steady state 
economy in the mid-19th century believed that after a period of growth, the economy would reach a stationary state, characterized by constant population and stocks of capital "It is scarcely necessary to remark that a stationary condition of capital and population implies no stationary state of human improvement. There would be as much scope as ever for all kinds of mental culture, moral and social progress; as much room for improving the Art of Living and much more likelihood of its being improved, when minds cease to be engrossed by the art of getting on".

Keynes (1933) predicted that, avarice is a vice that the exaction of usury is a misdemeanor, and the love of money is detestable. We shall once more value ends above means and prefer the good to the useful. And the day is not far off when the economic problem will take the back seat where it belongs, and the arena of the heart and the head will be occupied or reoccupied, by our real problems - the problems of life and of human relations, of creation and behavior and religion. Georgescu-Roegen (1971) asserts, the second law of thermodynamics, the entropy law, determines what is possible in the economy. He explained that useful, low-entropy energy and materials are dissipated in transformations that occur in economic processes, and they return to the environment as high-entropy wastes. The economy, then, functions as a conduit for converting natural resources into goods, services, human satisfaction, and waste products. Increasing entropy in the economy sets the limit on the scale it can achieve and maintain.

Boulding (1966) recognized the material and energy constraints of the economy and proposed a shift from the expansionist "cowboy economy" to the conservative "spaceman economy." In the cowboy economy, success is gauged by the quantity and speed of production and consumption. In the spaceman economy, by contrast, "what we are primarily concerned with is stock maintenance, and any technological change which results in the maintenance of a given total stock with a lessened throughput (that is, less production and consumption) is clearly a gain." Georgescu-Roegen's (1971) fourth law of thermodynamics, unlimited growth is physically impossible. Samuelson (1943) the stationary economy was considered as some kind of equilibrium condition that needed to be understood in terms of capital formation and depreciation, interest rates, and the business cycle. Andreas (2010) finds that in a neoclassical economy with endogenous capital- and labor-augmenting technical change the steady-state growth rate of output per worker is shown to increase in the elasticity of substitution between capital and labor.

The Early Economist as stated above has theorize steady state economic growth but no or little has been done empirically to explain stationary state of economic growth in Nigeria. Hence the need to carry out this research to shed light on the theoretical postulation. 


\section{Methodological Framework}

This paper uses a Vector Auto Regression to identify the relationship between Economic growths (Steady state), interest rate, Population growth, Rate of Depreciation. $\mathrm{Y}=\mathrm{f}(\mathrm{INT}, \mathrm{POP}, \mathrm{DEP})$

In an explicit and econometric form, equation (1) can be stated as $\mathrm{LY}_{\mathrm{t}}=\alpha_{0}+\alpha_{1} \mathrm{LINT}+\alpha_{2} \mathrm{LPOP}_{\mathrm{t}}++\alpha_{3} \mathrm{LDEP}_{\mathrm{t}}+\varepsilon_{\mathrm{t}}$

Where;

$\mathrm{LY}_{\mathrm{t}}$ is Economic growth (GDP)

LINT $_{t}$ is interest rate

$\mathrm{LPOP}_{\mathrm{t}}$ is the population growth rate

LDEP $_{\mathrm{t}}$ is depreciation rate (\% of domestic demand)

$\alpha_{0}$ is the constant term, " $\mathrm{t}$ " is the time trend, and " $\mathrm{t}_{\mathrm{t}}$ " is the stochastic random term. Following Legrenzi \& Milas, (2002) nominal values were used in order to avoid the difficulty of identifying an appropriate deflator for the series of variables. Data used for this analysis is for 42 years from 1970 to 2012 for Nigeria from World Development indicators (2013), World Bank website.

\section{Determination of unit roots}

In order to test the analyzed stationary variables, the Augmented Dickey-Fuller (ADF) test and Philip and Perron (PP) were applied, based on the following regression:

$$
\Delta \mathrm{y}_{\mathrm{t}}=\alpha_{0}+\alpha_{1} \mathrm{y}_{\mathrm{t}-1}+\sum_{i=1}^{n} \alpha 1 \Delta \mathrm{yi}++\mathrm{e}_{\mathrm{t}}
$$

Where;

" $y$ " is a time series, " $t$ " is a linear time trend, " $\Delta$ " is the first difference operator, " $\alpha_{0}$ " is a constant, " $n$ " is the optimum number of lags on the dependent variable and " $\mathrm{e}$ " is the random error term. The difference between equation (1) and (2) is that the first equation includes just drift. However, the second equation includes both drift and linear time trend. This study also employs the Philip-Perron test due to Phillips (1987) and Phillips and Perron (1988). Since the possibility of the presence of structural breaks makes the ADF test unreliable for testing stationarity. The presence of a structural break will tend to bias the ADF test towards non-rejection of the null hypothesis of a unit root. The regression equation for the PP test is given by

$$
\Delta \mathrm{y}_{\mathrm{t}}=\alpha+\beta \mathrm{Y}_{\mathrm{t}-1}+\mathrm{e}_{\mathrm{t}}
$$

\section{Empirical Analysis \\ Testing for Unit Root}

First is to test if the relevant variables in equation (2) are stationary and to determine their orders of integration. I use both the Augmented Dickey Fuller (ADF) and Phillips - Perron (PP) tests to find the existence of 
unit root in each of the time series. The results of both the ADF and PP tests are presented in Table 4.1.1 and 4.1.2.

Table 4.1.1. Testing for Unit Root

\begin{tabular}{|c|c|c|c|c|}
\hline VARIABLES & ADF(INTERCEPT) & $\begin{array}{c}\text { ADF(INTERCEPT } \\
\text { \&TREND } \\
\end{array}$ & PP(INTERCEPT) & PP(INTERCEPT \&TREND \\
\hline LY & $\begin{array}{c}-2.168(-3.596) *(- \\
2.933) * * \\
2.604) * * *\end{array}$ & $\begin{array}{c}-2.160(-4.192)^{*} \\
(-3.520)(- \\
3.191) * * *\end{array}$ & $\begin{array}{c}-2.112(-3.596)^{*} \\
(-2.933)^{* *(-}(- \\
2.604)^{* * *}\end{array}$ & $\begin{array}{c}-2.094(-4.192) *(- \\
3.520) * *(-3.191) * * *\end{array}$ \\
\hline LIR & $\begin{array}{c}-1.798(-3.596) *(- \\
2.933) * * \\
2.604) * * *\end{array}$ & $\begin{array}{c}-1.833(-4.192)^{*} \\
(-3.520)(- \\
3.191) * * *\end{array}$ & $\begin{array}{c}-1.848(-3.596)^{*} \\
(-2.933) * *(- \\
2.604)^{* * *}\end{array}$ & $\begin{array}{c}-1.931(-4.192) *(- \\
3.520)^{* *}(-3.191) * * *\end{array}$ \\
\hline LPOP & $\begin{array}{c}-1.979(-3.596) *(- \\
2.933) * * \\
(-2.604)^{* * *}\end{array}$ & $\begin{array}{c}-1.976(-4.192)^{*} \\
(-3.520)(- \\
3.191) * * *\end{array}$ & $\begin{array}{c}-1.979(-3.596) * \\
(-2.933) * *(- \\
2.604) * * *\end{array}$ & $\begin{array}{c}-2.015(-4.192) *(- \\
3.520) * *(-3.191)^{* * *}\end{array}$ \\
\hline LDEP & $\begin{array}{c}-1.654(-3.596) *(- \\
2.933)^{* *} \\
(-2.604)^{* * *}\end{array}$ & $\begin{array}{c}-1.849(-4.192)^{*} \\
(-3.520)(- \\
3.191) * * *\end{array}$ & $\begin{array}{c}-1.654(-3.596) * \\
(-2.933) * *(- \\
2.604) * * *\end{array}$ & $\begin{array}{c}-1.894193(-4.192) * \\
(-3.520) * *(- \\
3.191) * * *\end{array}$ \\
\hline
\end{tabular}

Note: $*$, ** and $* * *$ denote significance at $1 \%, 5 \%$ and $10 \%$ level, respectively.

Figures within parenthesis indicate critical values. Mackinnon (1996), critical value for rejection of hypothesis of unit root applied.

Source: Author's Estimation using Eviews 7.0.

The result in table 4.1.1 shows that all the variables were not stationary at levels. This can be seen by comparing the observed values (in absolute terms) of both the ADF and PP test statistics with the critical values (also in absolute terms) of the test statistics at the 1\%,5\% and 10\% level of significance. Result from table 4.1.1. provides strong evidence of non stationarity. Therefore, the null hypothesis is accepted and it is sufficient to conclude that there is a presence of unit root in the variables at levels, following from the above result, all the variables were differenced once and both the ADF and PP test were conducted on them, the result as shown in table 4.1.2

\section{Testing for Unit Root}

\begin{tabular}{|c|c|c|c|c|}
\hline VARIABLES & ADF(INTERCEPT) & $\begin{array}{c}\text { ADF(INTERCEPT } \\
\text { \&TREND } \\
\end{array}$ & PP(INTERCEPT) & PP(INTERCEPT \&TREND \\
\hline LY & $\begin{array}{c}-7.420(-3.600) *(- \\
2.935) * * \quad(- \\
2.605) * * *\end{array}$ & $\begin{array}{c}-7.417(-4.198) *( \\
-3.523) * *(- \\
3.192) * * *\end{array}$ & $\begin{array}{c}-7.460(-3.600) * \\
(-2.935) * *(- \\
2.605) * * *\end{array}$ & $\begin{array}{c}-7.613(-4.198) *(- \\
3.523) * *(-3.192) * * *\end{array}$ \\
\hline LIR & $\begin{array}{c}-5.218(-3.600) *(- \\
2.935) * * \quad(- \\
2.605) * * *\end{array}$ & $\begin{array}{c}-5.079(-4.198)^{*} \\
(-3.523)^{* *}(- \\
3.192)^{* * *}\end{array}$ & $\begin{array}{c}-5.218(-3.600) * \\
(-2.935) * *(- \\
2.605) * * *\end{array}$ & $\begin{array}{c}-5.079(-4.198) *(- \\
3.523) * *(-3.192) * * *\end{array}$ \\
\hline LPOP & $\begin{array}{c}-5.605(-3.600) *(- \\
2.935) * * \quad(- \\
2.605) * * *\end{array}$ & $\begin{array}{c}-5.469(-4.198) * \\
(-3.523) * *(- \\
3.192) * * *\end{array}$ & $\begin{array}{c}-5.605(-3.600) * \\
(-2.935) * *(- \\
2.605) * * *\end{array}$ & $\begin{array}{c}(-4.198) *(-3.523)^{* *}( \\
-3.192)^{* * *}\end{array}$ \\
\hline LDEP & $\begin{array}{c}-5.930(-3.600) *(- \\
2.935)^{* *}(- \\
2.605) * * *\end{array}$ & $\begin{array}{c}-5.846(-4.198)^{*} \\
(-3.523) * *(- \\
3.192) * * *\end{array}$ & $\begin{array}{c}-5.930(-3.600)^{*} \\
(-2.935) * *(- \\
2.605) * * *\end{array}$ & $\begin{array}{c}(-4.198)^{*}(-3.523)^{* *} \\
-3.192)^{* * *}\end{array}$ \\
\hline
\end{tabular}


Note: $*$, ** and $* * *$ denote significance at $1 \%, 5 \%$ and $10 \%$ level, respectively.

Figures within parenthesis indicate critical values. Mackinnon (1996), critical value for rejection of hypothesis of unit root applied.

Source: Author's Estimation using Eviews 7.0.

Table 4.1.2, reveals that all the variables became stationary at first difference, on the basis of this, the null hypothesis of non-stationary is rejected and we can safely conclude that the variables are stationary. This implies that the variables are integrated at order one, that is I(1).

\section{Co-integration Test Result}

Having found that the variables are stationary at $1(1)$, we proceed to determine the presence or non presence of co-integration among the variables. When a co-integration relationship is present, it means that Economic growth, Interest rate, Population growth and depreciation share a common trend and long-run equilibrium as suggested theoretically. We start by co-integration analysis by employing the Johansen and Juselius multivariate co-integration test.

Table 4.2.3

Unrestricted Co-integration Rank Test (Trace)

\begin{tabular}{lllll}
\hline \hline $\begin{array}{l}\text { Hypothesized } \\
\text { No. of CE }(\mathrm{s})\end{array}$ & Eigenvalue & $\begin{array}{l}\text { Trace } \\
\text { Statistic }\end{array}$ & $\begin{array}{l}0.05 \\
\text { Critical Value }\end{array}$ & Prob.** \\
\hline \hline None* & 0.472830 & 43.03828 & 40.17493 & 0.0448 \\
At most 1 & 0.196421 & 12.78873 & 24.27596 & 0.6395 \\
At most 2 & 0.086066 & 3.822848 & 12.32090 & 0.7363 \\
At most 3 & 0.003238 & 0.132960 & 4.129906 & 0.7636 \\
\hline \hline
\end{tabular}

Trace test indicates 1 cointegration at the 0.05 level

$*$ denotes rejection of the hypothesis at the 0.05 level

**MacKinnon-Haug-Michelis (1999) p-values

\section{Unrestricted Cointegration Rank Test (Maximum Eigenvalue)}

\begin{tabular}{lllll}
\hline \hline $\begin{array}{l}\text { Hypothesized } \\
\text { No. of CE(s) }\end{array}$ & Eigenvalue & $\begin{array}{l}\text { Max-Eigen } \\
\text { Statistic }\end{array}$ & $\begin{array}{l}0.05 \\
\text { Critical Value }\end{array}$ & Prob.** \\
\hline \hline None $*$ & 0.472830 & 26.24955 & 24.15921 & 0.0257 \\
At most 1 & 0.196421 & 8.965882 & 17.79730 & 0.5982 \\
At most 2 & 0.086066 & 3.689888 & 11.22480 & 0.6781 \\
At most 3 & 0.003238 & 0.132960 & 4.129906 & 0.7636 \\
\hline \hline
\end{tabular}

Max-eigenvalue test indicates 1 cointegrating eqn(s) at the 0.05 level

$*$ denotes rejection of the hypothesis at the 0.05 level

**MacKinnon-Haug-Michelis (1999) p-values

Ensuing stationarity test is the examination of the long run (cointegration) relationship among the variables. The Johansen multivariate cointegration technique was adopted rather than the Engel-Granger techniques. 
This was based on the two reasons, first, the variable for analysis are I(1) series which is a pre-conduction for the adoption Johansen techniques and secondly, the model is a multi-variate as specified in model Equation 2, consequently, there is a possibility of having $>1$ co-integration vector in the model. This is against Engel-Granger techniques which are only suitable for testing co-integration between two variables. The result obtained from Johansen multivariate co-integration method is shown in tables 4.2.1and 4.2.2. The null hypothesis of no co-integration of $r=0$ and $r \leq 1$ in the model was reject in the trace statistics and maximum Eigen value statistics.

The statistical value of these test were greater than the critical values, however, the null hypothesis, that is, $r \leq 2$ could not be rejected in both the trace statistics and Maximum Eigen value statistics because their values were less than the critical values implying that there are at less two co-integrating vector among the series. The implication of this result is that there exist a long-run relationship among the series and hence we would go ahead to estimate the error correction model (ECM) to determine the speed of adjusted in the short-run to it long run equilibrium state.

Error Correction Result

Table 4.2.4.

\begin{tabular}{|c|c|c|c|c|}
\hline Error Correction: & D(LGDP) & D(LINT) & D(LPOP) & D(LDEP) \\
\hline & -0.032127 & -0.090932 & -0.062975 & -0.049544 \\
& $(0.54275)$ & $(0.73432)$ & $(0.56116)$ & $0.58697)$ \\
& {$[-2.43442]$} & {$[-1.23833]$} & {$[-1.12224]$} & {$[-0.84406]$} \\
\hline
\end{tabular}

Table 4.3.2 shown the result of error correction model for each of the variables involve in the analysis, LGDP has a negative coefficient of -0.032 which shows the speech at which it revert back to it long run equilibrium (Steady state) that is 3.2 percentage change or moving away from the steady state is corrected each year. It implies that the GDP is moving 3.2 percentage each year toward the steady state, the interest rate is Lint also has negative 0.090 implying that about 9.0 percent of the shift are corrected each year and that the interest rate is moving toward it steady state by 9.2 percent each year, LPOP is -0.062 imply that 6.2 percent of disequilibrium is corrected every year and it then imply that Population is moving 6.2 percent closer to its steady state each years and also for the LDEP is negative too with the value -0.049 , implying that 4.9 percent of shift away from equilibrium is corrected each year, it then means that depreciate rate of the economy is moving toward its steady state each year by 4.9 percent in the economy.

\section{Conclusion}

The premise of this paper has been prediction of steady state of the Nigeria's economy. The data used covers the period of 1970-2012, using the 
Vector Autoregressive co-integration test procedure. The results show that the variables were not stationary at level and they became stationary at first differencing and integrated of I(1). A long run relationship was also found to exist among Gross Domestic product (GDP), Interest rate, population growth and depreciation rate. The error correction test indicating that the model has a self-adjusting mechanism for correcting any deviation of the variables from equilibrium. The implication of this is that GDP will reach it steady state in 31to 32years, interest rate will reach it steady state in 11 to 12 years, population growth will reach steady state in 16 to 17 years and depreciation rate will become stationary in 20 to 21 years in Nigeria economy.

It is therefore suggested that policy makers should (1) strive to increase the level production at the moment and moderate it in a future as we have not reach the golden state of production yet, (2) interest rate should be reduced to boost investment which will ultimately increase productivity, (3) policy aims at moderating population growth rate should be encouraged and (4) lastly, infrastructural facilities should be put in place to augment the existing ones which will go a long way in reducing the depreciation of fixed capital in the economy.

\section{References:}

Andreas, I. (2010) Steady-state growth and the elasticity of substitution, University of Heidelberg and CESifo, Munich, Discussion Paper Series No. 496, JEL: E22, O11, O33, O41

Boulding, K. E. (1966) at the Sixth Resources for the Future Forum on Environmental Quality in a Growing Economy in Washington, D.C. on March 8,1966.

Daly, H. (1991) Steady-State Economics, $2^{\text {nd }}$ edition. Island Press, Washington, DC.

Georgescu-Roegen , N. (1971) The Entropy Law and the Economic Process, www.steadystate.org, retrieved on $25^{\text {th }}$ October, 2013.

Georgescu-Roegen, N. (1977). "The Steady State and Ecological Salvation: A Thermodynamic Analysis." BioScience 27(4): 266-270.

Legrenzi, G. and Milas, C. (2002), "Asymmetric and non-linear adjustment in the revenue-expenditure models", Department of Economics and Finance, Brunel University, UK.

Mill, J. S. (1909) Principles of Political Economy. William J. Ashley. Library of Economics and Liberty

Shucmacher, E. F. (1999) Small is Beautiful: Economics as if people mattered: 25 years later, Hartley \& Marks Publishers ISBN 0-88179-169-5.

Samuelson, P. A. (1943). Dynamics, statics, and the stationary state. The Review of Economics and Statistics , 25 (1), 56-68.

www.worldbankgroup.com. Retrieve on $17^{\text {th }} / 11 / 2013.5: 35 \mathrm{pm}$ 